\title{
CSR in the Digital ERA - a Access on the CSR Communication of Companies and Identification of Services for CSR
}

\author{
Janani .V, S.Gayathri
}

\begin{abstract}
Corporate social responsibility has undergone changes due to the advent of the digital era. This study looks into such digital innovation and trends that have taken place in this era and also the future trends that we can expect. This paper examines the trends that have taken place and the recent innovations in corporate social responsibility, in the digital front.It also highlights the gaps in the technological advancements that are yet to be filled in CSR. An attempt has been made to bring out the advantages of the CSR communication in the digital era and the challenges involved in it.
\end{abstract}

Keywords: Corporate social responsibility, digital era, communication, challenges, Stakeholders.

\section{INTRODUCTION}

With the change of time, due to the fourth industrial revolution where the technology has become the norm, we see that the Corporate have tried to accommodate digital technologies into CSR as well. The emergence of the term "Digital Divide" denotes how the spread of technologies have changed completely the basic life style of the human kind. The world has literally transformed so much that it is in our finger tips. We see that the firms are now doing technology based corporate social responsibilities such as provision of free Wi-Fi and setting up of computer research labs in the remote villages in India by companies like Alphabet Inc.(Google), Apple and Microsoft and strive to bring about net neutrality, as a part of CSR in this era.

In countries like India, where CSR had been mandatory, companies adopt a slew of measures in order to comply with the mandatory CSR. These are repetitive in nature and there is also the question whether it reaches the real beneficiaries based on what is actually needed by them. The digital technology can come to the aid so that CSR could be incorporated, right from the business and delivered to the needy. The technology provides CSR the data which is absolutely necessary to know the basics of whom to provide the services and what is needed by them. Technology broadens the business' horizon and due to the advent of technology the businesses are not stuck to provide services to the local area alone they can go global.

\section{The growth of digital communication in business}

The digital technology makes it easier to communicate CSR to the stakeholders with the help of technologies such as social media. A company could identify the needs and

Revised Manuscript Received on September 10, 2019.

Mira Janani .V, Research Scholar,School of Management Studies, Vels Institute of Science, Technology \& Advanced Studies, Chennai, Tamilnadu, India.

Dr.S.Gayathri, Associate Professor, School of Management Studies, Vels Institute of Science, Technology \& Advanced Studies, Chennai, Tamilnadu, India. problems of stakeholders, quickly by using their data. Digital technology has also enabled the finding of the cost effective ways in which CSR could be performed which are technologically advanced and are more efficient than the traditional methods. It becomes easier for the companies to store the information regarding the CSR performed and also it becomes easier for them to quantify it by looking into the publicly available CSR data of the similar companies. Business becomes closer to the stakeholders and also attains the position in which it can take the opinions of them before implementing a CSR activity. This obviously leads to the Increase in the goodwill of the company. Global benchmarking of the CSR practices is possible due to the digitalization. Every coin has two sides. Similarly the digitalization of CSR has its fair share of disadvantages to:

- The data available online of the stakeholders may not be completely reliable.

- In the remote areas providing CSR related to technology may not be well received unless there is a supporting ecosystem for it.

- $\quad$ Before providing cost efficient technology focused service to a remote area, there should be a progamme to spread awareness among the people as to how to use the technology that has been provided which may not be that easy.

- $\quad$ Sometimes a country's law may prevent a company from going global with their CSR activities.

- Data on the underprivileged rural people who actually are in need of CSR activities by the corporate may not be available digitally in all regions.

- Some companies may invade the privacy of the users and misuse the data provided under the pretext of CSR.

- Just as it is easy to communicate CSR activities of the company to the outside world through social media similarly it is quite easy to spread false news on the CSR activities done by the company in social media so the stakeholders coming across this information in the social media may be skeptical.

But in spite of the disadvantages stated, there is no denying the fact that digitalization does indeed make the process of CSR more efficient and provides a base for the companies to carry on their CSR activities thus removing the gaps in technologies. The right service should be chosen and errors be removed and focus should be made on fine tuning the technologies in such a way that no CSR services provided by the companies with the means of technologies in this digital era goes waste.

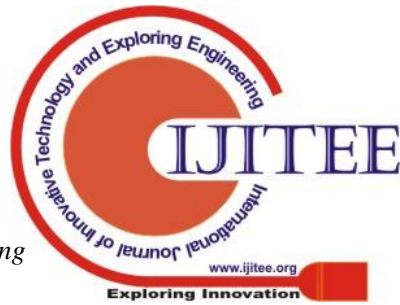




\section{CSR in the Digital ERA - a Access on the CSR Communication of Companies and Identification of Services for CSR}

\section{CSR IN THE DIGITAL ERA}

The human kind is now in an era where the people of the era may be known as the "digital natives" Prenksy, 2001 (1). We find that e-governance defined as "way for governments to use the most innovative information and communication technologies, particularly web-based Internet applications, to provide citizens and businesses with more convenient access to government information and services, to improve the quality of the services and to provide greater opportunities to participate in democratic institutions and processes" given by Fang (2002) (2).In the corporate world, it is not a surprise that the whole structure of the organizations have changed and being a part it, the corporate social responsibility has seen its fair share of changes due to the technological advancements. If we take a look at the first known definition of CSR by Bowen (1953) (3), it goes as,"The obligations of businessmen to pursue those policies, to make those decisions, or to follow those lines of action which are desirable in terms of the objectives and values of our society." This definition talks about providing value by giving back to the society which provides the business with resources. That is running the business in such a way that it is of a maximum advantage to the parties involved in the triple bottom approach that is "People, profit and Planet" (4) It is essential that companies should realize their part in building a sustainable environment, in which every stakeholder in the supply chain is values. It could be the workers, customers, community and anyone involved. There is no pint in doing a sustainable business, creating pollution and then practicing CSR to the communities.

How would you know what to provide whom? How can you know what value you should provide to the society? This is where technology steps in the use of social media, systems software and many such technological advancements has made CSR easier to communicate and also more efficient. We see that in accordance of CSR the needs of the people remains the same just the way the corporate approach those needs has changed. The first change we may say is the needs of the corporate to communicate it to the world. The second change that technology has brought in CSR is the way to communicate with the people for whom the CSR is performed. Due to the technological advancements it is easier to know what the people actually want. The third change is the way CSR in itself is being performed. We see the emergence of research centers in colleges and making the students from backwards communities technologically advanced as also a part of CSR.

\section{OBJECTIVES}

- To review the literature on the CSR activities with the help of technology and the benefits for the stakeholders involved in the triple bottom approach.

- To study the role of digital communication of CSR to stakeholders.

\section{RESEARCH METHODOLOGY \& RESULTS}

The paper had followed a conceptual approach .A review of the literature on digital CSR had been done in the study. A total of ten papers had been reviewed on this aspect.
These are researches after 2010, as the concept had gained momentum only after that, due to the advent of digital technology. In India, the mandatory CSR had also been introduced in 2013, by way of the New Companies Act, 2013. Hence this study had focused on the recent reviews to get an idea on the concept, which would be incorporated in further research,

\section{LITERATURE REVIEW}

Borger (2006) in his research discusses about including technological advancement as its goal in the CSR activities would affect the company. Three companies from Brazil were chosen to participate in this study namely De Nadai Alimentação a catering company, DaimlerChrysler Ltd., a car company and Natura Cosmetics, a cosmetics company. The companies were divided into 2 time periods before including technology into its CSR also called as Social Environmental Responsibility (SER) model and after including technology into its CSR model (SER model). The independent variable is "Strategy" comprising of leadership, policies, top management support and procedures relating to the SER model and the dependent variables "Enterprise dynamics" comprising of Organizational climate, Enterprise's operational and environmental performance and Innovation capacity. The intervening variable here is "Context" comprising of sector, number of employees, sales, ownership origin and enterpriser's age. This research was in two phases one was the bibliographic reviews of the similar cases and the other was from the primary data obtained by conducting in-depth interviews from the managers of the companies the primary data was thus subject to regression analysis. The study shows the result that the inclusion of technology advancement in the SER model has a positive influence on the enterprise dynamics of the organization. (5)

Chaudhri and Wang (2014) in their paper analyzed the extent of CSR communication in the websites of the companies. The source of data being secondary, 100 websites of companies both from India and abroad were analyzed forinformation on the following front

a) Responsibilities to customers and other stake holders b) Responsibility to the community and c) Responsibility to the environment taken from the article of Basser 1998(6) to determine the extent of the CSR information available in the website out of that only 30 companies had information of CSR on their websites 18 being Indian companies and 12 being Foreign companies. The 30 companies thus selected were analyzed for placement of CSR on the corporate website, an indication of communication prominence, extent of information dedicated by number of pages available in the website, and CSR related documents available in the website taken from the article of Chambers et al., (2003) (7) and Pollach(2003)(8). The study concludes by saying that, out of 30 companies one third $(36.6 \%)$ had promissory link to CSR. In the prominence only half of the companies $(43.3 \%)$ qualified in the minimal information category with a one page information on CSR and $36.6 \%$ of the companies had a m 
b) Medium coverage of 3-10 pages and $20 \%$ of the companies had an information coverage of more than 10 pages. Another interesting find is that global companies had less coverage about CSR than the local companies.(6)

Chopra (2012) in his paper proposes 3 technological means of services that can be provided as the part of CSR. The data is secondary taken from articles, books and also from the website information of TCS the place of work for the author. The author proposes 3 technology led innovative CSR that could be provided by TCS to its people. The first one being Swach- Low cost affordable water purifier which uses cutting edge and Nano technology and natural materials. It was developed targeting the rural households in India. The second one being, Krishi- The mobile agro advisory system - it is an internet based farmer advisory system for helping farmers by using multimedia platforms. The third one being Adult Literacy Progamme(ALP) which makes used of Computer Based Functional Literacy(CBFL) which uses flash cards, animated computer designs which reduces the hour of learning required to 40 to 45 hours. The study concludes by saying that technology has the potential to be a game changer in the societal problems and viewing CSR through the lens of the system allows the companies to look at the problems through holistic perspective.(7). Companies can intertwine technology in their CSR activities so that maximum beneficiaries make use of it, thus underlying the Utilitarian concept.

Colleni (2013), through his research had discussed the extent of communication of CSR in the social media. The data was secondary and the social media chosen to analyze was twitter. The time period taken was June to December 2009. The companies were selected from the 100 best corporate lists published in the year of 2009 by the "Corporate responsibility magazine". The twitter accounts of the seven companies Starbucks, Ford, Microsoft, Campbell, Smarter planet, Xcel energies and Green Mountain coffee Roasters were takenand the social graphs were identified and the first CSR community with 16000 users were taken. Out of that filtering to get only the CSR related content 3000 tweets were manually coded. The study had two research questions a) What are the characteristics of CSR communication in social media and $b$ ) is there an alignment between companies' CSR agenda and stakeholders' social expectations in social media? If there is an alignment do the different communication strategies lead to different alignment outcomes? Data mining logarithm was used and based on the node percentage shared among the companies, the study investigates the shared audiences determining the friendliness of communication of the company with the public. The results showed that the highest being 11.45 percent between Microsoft and Campbell and the lowest being between Microsoft and Green Mountain. The average shared node is $4 \%$. The study interprets that the company which is of the category of friendly interacts more with the audience regarding CSR. The study also interprets that there is no convergence between the stake holder expectations and the CSR communication. (8)

Ahmad (2016) talks about the CSR communication practices in the social media among the award winning companies. The recording of number of likes shares and comments of the stakeholders on the posts relating to CSR was made. The data has been analyzed using thematic analysis. The data was from June 2015 to June 2016. Of all the posts of the company in these social media more than $52 \%$ were about CSR. The posts concentrated on the achievements made by CSR. Thus the study concludes by saying that an award winning company for social responsibility tends to be more dominant in the social media regarding its communication of CSR to the stakeholders.(9)

Lee et al., (2013) talks about how the online communication of CSR in the social media and the online presence of the company affects its CSR rating. The data collected was secondary data of the fortune 500 companies from the company's websites and were further filtered out taking only the companies with CSR ratings, which made the total number of samples to be 405 . And out of that the companies having the twitter accounts were filtered out leaving the final sample to be 222 companies with CSR ratings and a twitter account among the fortune 500 companies. The study has 4 hypotheses. The research analyzed the significance between the firm's CSR rating and online presence, social media communications, user driven communications The independent variables being number of followers, number of retweets and number of tweets by the company. The analysis was done from the dates of May 12 to May 25 2012. The analysis was done by using probit regression model. The study concluded that high online presence and the communication of the CSR activities is more for the companies with the high CSR ratings. (10)

Illia et al., (2015) examines how a company engages in the CSR communication in the social media. The data collected is primary data which was collected in 3 stages the first stage being Exploring Expected Corporate Online Spaces from Stakeholders' Perspectives for this 40 in-depth, semi structured interviews with 10 different stakeholder profiles was conducted and the stake holders profiles were divided into the categories of employees active in CSR projects, investors owning shares of companies in CSR indexes (or analysts evaluating CSR indexes), governmental agencies active in the CSR area, educational actors the interviewing was done using the snowballing method. The second stage was to identify the online spaces where CSR dialogues took place and this made use of secondary data 33 different CSR indices. The third stage was to analyse the actual dialogue taking place, which was a secondary data of in-depth analysis of 150 such dialogues. The analysis was done by qualitative theory building conducted in 3 stages The findings indicate that that stakeholders expect three ideal online CSR dialogue spaces (1) space for co-learning, (2) space for co-innovating, and (3) space for co-deciding. The second main finding indicates was that stakeholders expect companies to engage in dialogue spaces that allow everybody (i.e. the company, users, etc.) to be open to new ways of innovating in the implementation and promotion of CSRrelated matters. Stakeholders feel that corporations have been setting the agenda for a long time, and they often question the way CSR-related matters have been managed. Another finding that emerged from our data structure was 
that respondents speaking as stakeholders expected a third online CSR dialogue space around co-deciding. However, although they found great benefit in these types of outlets, they also noted that these spaces are especially controversial. (11)

Kent and Taylor (2016) in their review paper, talk about the alternative ways in which the social media can be used for the CSR communication. This paper has been divided into three sections the first section which talks about CSR as an activity that involves establishing relationship with the stakeholder this approach in the paper has been termed as "Homo Economicus" this contains the usage of social media as it has been done traditionally. Then the second section of the paper looks at the means through which CSR can be communicated to the outside world and the various obstacles that come in the path that prevent the communication from being effective the third section of the paper proposes a different way in which CSR information can be communicated altogether and offers a fresh perspective of the usage of social media for the CSR purposes termed as "Homo Dialogicus" in the paper. The study concludes with three findings which advocate to first start a social media site specific to the company. Second make it open for the members to discuss the issues of CSR and third analyze the worth of the members and then admit them into the networking site. (12)

Tomaseli and Melia (2014) discuss how the corporate communicate their CSR activities through social media. The companies analyzed were 3 Italian companies the Hera Group, Telecom Italia and Eni chosen on the basis of the receipt of CSR online excellence award in the year of 2012. The data for the purpose of this study was collected in three phases. The first phase being analyzing the social media profiles of the company like Face book, Twitter, Google+, Flickr, Slide share, You Tube, Pinterest, LinkedIn and Instagram. The second phase consisted of collecting both primary and the secondary data the secondary data collected through various sources such as the company websites, similar documents and articles that address a similar topic. The primary data was obtained by interviewing in depth the CSR managers of the companies that have been taken for the analysis. The third phase was concentrated on analyzing the available data. The study concluded with five findings. Even though the companies are communicating CSR to the public the reasons of communication may differ. The second finding is that the communication of CSR to the outside world has been viewed as important and the reasons as to why they are important vary from company to company. The third finding is that to communicate their CSR activities the companies use traditional as well as non-traditional channels of communication. The fourth finding is that the companies look upon the alternative uses of social media. The fifth finding is that the firms are willing to continue and even improve the means of communicating CSR with the stakeholders. (13)

Kesavan et al., (2013) talk about the importance of using social media for communicating the CSR activities of the company with the outside world the paper compares the traditional CSR activities and talks about how to communicate the CSR activities with the outside world. The paper takes upon the social media applications of twitter,
Face book, blogs and YouTube and describes how the CSR communication can be done through them. For twitter the case study used is the Zappos Company by the means of twitter Zappos establishes a close contact with its customers and gets to know their needs. For Face book the case study used is IKEA through Face book IKEA communicates its policies and values to its customers thus attracting customers through its values and giving a platform for the customers to express their needs. For blogs the case study used is McDonalds which has a blog dedicated to communicating CSR activities of the company with the stakeholders. The managers and the experts in the CSR division make regular contributions to the blog which has a high rating. For YouTube the case study used is $P \& G$ which makes videos of its CSR activities by making viral campaigns. The paper thus concludes that taking such case studies as examples companies can communicate CSR to its stake holders through social media. (14)

\section{CONCLUSION}

Thus we see the role technology plays in CSR and the gaps in which CSR has to advance technologically. Better CSR communication and use of technologies in CSR and makes the process more efficient. Identifying the technological gap and bringing out CSR policies that are centred on removing this gap is the way forward. Improvements need to bemade on the communication of CSR in the social media platforms and also on usage of cost reducing technologies. This study is not without limitations as this is a review of the existing literatures. This study is solely based on the qualitative analysis and should be quantified to get a clearer picture.The scope lies in conducting a Meta-analysis and then selecting a sample group, to evaluate the digital CSR efficiency.

\section{REFERENCES}

1. Prensky, M. (2001). Digital natives, digital immigrants part 1. On the horizon, 9(5), 1-6.

2. Fang, Z. (2002). E-government in digital era: concept, practice, and development. International journal of the Computer, the Internet and management, 10(2), 1-22.

3. Bowen, H. R., \& Johnson, F. E. (1953). Social responsibility of the businessman. Harper.

4. Slaper, T. F., \& Hall, T. J. (2011). The triple bottom line: What is it and how does it work. Indiana business review, 86(1), 4-8.

5. Borger, F. G., \& Kruglianskas, I. (2006). Corporate social responsibility and environmental and technological innovation performance: case studies of Brazilian companies. International Journal of Technology, Policy and Management, 6(4), 399-412.

6. Chaudhri, V., \& Wang, J. (2007). Communicating corporate social responsibility on the internet: A case study of the top 100 information technology companies in India. Management Communication Quarterly, 21(2), 232-247.

7. Chopra, S. K. (2012, October). Leveraging technological advances in corporate social responsibility (csr): A systems thinking approach. In 2012 IEEE Global 
Humanitarian Technology Conference (pp. 122-127). IEEE.

8. Golob, U., Elving, W. J., Nielsen, A. E., Thomsen, C., Schultz, F., Podnar, K., \& Colleoni, E. (2013). CSR communication strategies for organizational legitimacy in social media. Corporate Communications: an international journal.

9. Ahmad, Z. (2016). Communicating CSR in the digital age: An exploratory study of a CSR award winning company in Malaysia. Journal of Education and Social Sciences, 4, 1-6.

10. Lee, K., Oh, W. Y., \& Kim, N. (2013). Social media for socially responsible firms: Analysis of Fortune 500's Twitter profiles and their CSR/CSIR ratings. Journal of business ethics, 118(4), 791-806.

11. Illia, L., Romenti, S., Rodríguez-Cánovas, B., Murtarelli, G., \& Carroll, C. E. (2017). Exploring corporations' dialogue about CSR in the digital era. Journal of Business Ethics, 146(1), 39-58.

12. Kent, M. L., \& Taylor, M. (2016). From Homo Economicus to Homo dialogicus: Rethinking social media use in CSR communication. Public Relations Review, 42(1), 60-67.

13. Tomaselli, G., \& Melia, M. (2014). The role of interactive technologies for CSR communication. Journal of International Scientific Publications: Economy \& Business, 8, 324-340.

14. Kesavan, R., Bernacchi, M. D., \& Mascarenhas, O. A. (2013). Word of mouse: CSR communication and the social media. International Management Review, 9(1), 58-66. 